\title{
Rhubarb (Rheum species): the role of Edinburgh in its cultivation and development
}

\author{
MR Lee ${ }^{1}$, J Hutcheon², E Dukan³, I Milne ${ }^{4}$
}

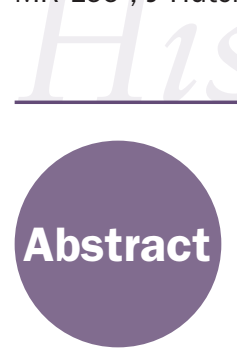

Rhubarb was grown and used throughout China for thousands of years. It then found its way to St Petersburg where the Romanovs developed a flourishing trade in the plant to the rest of Europe. James Mounsey, a physician to the Tsar, brought back seeds from Russia to Scotland at considerable risk to himself. He passed some of the seeds to Alexander Dick and John Hope. Both these physicians then grew rhubarb at

Correspondence to: MR Lee

112 Polwarth Terrace Merchiston

Edinburgh EH11 1NN UK Prestonfield and the Botanic Garden (both in Edinburgh), respectively. Eventually rhubarb, in the form of Gregory's powder, became a common and popular medicine throughout the UK.

Keywords Dick, Gregory, Hope, laxative, Mounsey, rhubarb, Royal College of Physicians of Edinburgh, St Petersburg

Declaration of interests No conflicts of interest declared

\section{Introduction}

Rhubarb has a dramatic history that includes political assassination, espionage and the Romanov Empire. This paper sets out the kaleidoscopic story of the plant and why, perhaps, we should treat it with more respect as a drug, foodstuff and poison.

\section{The name rhubarb (or Rhabarb) ${ }^{1}$}

The Volga river was named Rha by the Romans and rhubarb was thought to originate from the lands beyond it. 'Barb' derives from the Greek 'barbaros' which means people living in Greece who could not speak their language (Attic). Hence rhubarb (from the Greek) means a plant growing beyond the Volga.

\section{The plant}

The rhubarb genus comprises 50 species of coarse perennial herbs. They have tough woody roots, large long stalked leaves and clusters of small wind pollinated flowers. Rhubarb belongs to the family Polygonaceae which contains 300 species of plants including dock (Rumex acetosella) and wood sorrel (Oxalis acetosella). Well known species of rhubarb include acuminatum (Sikkim rhubarb), australe (Himalayan) and palmatum (Chinese or Turkish). Rheum $x$ hybridum is an ancient garden hybrid of unknown origin, which is widely used for puddings, preserves and in wine (the red stalks, not the roots or leaves).

\section{The active chemical constituents of rhubarb}

Until the 1850s the active principles of rhubarb were too difficult to isolate and characterise. In the last 150 years great progress has been made and a number of active dihydroxyanthraquinones have been isolated from the plant. These purgative compounds include chrysophenol, emodin and aloeemodin (Figure 1).

\section{Chinese rhubarb: Tai Huang ${ }^{2}$}

Many centuries before it was brought to the West, rhubarb was a common ingredient of Chinese herbal preparations, particularly San Chi Qi which was widely used as a laxative. The Romanov Empire derived its supplies from north-east China and established its monopoly of the plant through the years $1600-1800$ based on this source of supply.

\section{Greek and Arabic medicine and rhubarb}

Greek authorities on plants, such as Dioscorides and Theophrastus, were very familiar with rhubarb as a laxative. However, when the Greek civilisation was obliterated by the Romans (and others), a vast number of manuscripts were lost or destroyed. Fortunately, a number of Arabic scholars had visited Athens in this period and, on their return to Damascus and Baghdad, had carefully translated them into

Figure 1. Dihydroxyanthraquinones, the active compounds found in rhubarb

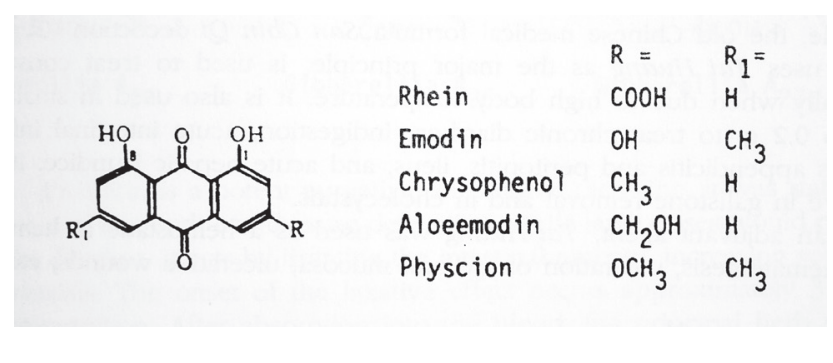


their own language. As a result, these translations were to play a major part in the great flourishing of Arabic medicine between the 9th and 14th centuries. Famous physicians include Avicenna, Mague and Rhazes. Mague developed a laxative pill containing rhubarb (and nine other components). It proved safe and effective.

\section{The rise of the English herbalists (the Age of Reason begins)}

Eventually specimens of rhubarb root appeared in Western Europe, probably coming from Italy or Spain. The actions of the extract of the root were then investigated. The famous English herbalist, Culpeper, ${ }^{3}$ took great interest in the root and his herbal of $1653^{4}$ described two separate preparations:

1. Electuarium dicatholico, the universal purging medicine which contained rhubarb and liquorice (the latter, a sweetener, was to help disguise the acrid taste of Rheum).

2. Syrupus de Cinchorio cum Rhabarbo which contained rhubarb, senna, ginger and other herbs.

Eventually rhubarb entered the Edinburgh Pharmacopoeia as Pilulae Rhei Compositae (rhubarb, aloes, myrrh and oil of peppermint with syrup of oranges). In the early 1800 s Gregory's rhubarb powder would replace these preparations in the Edinburgh and British Pharmacopoeias.

\section{The Romanov dynasty and the history of rhubarb $^{5}$}

When Peter the Great (1673-1725) came to the throne in 1696 he immediately embarked upon a number of important enterprises that he hoped would modernise Russia. He gathered together expatriates from many Western nations including Holland, France, Prussia and in particular Scotland. These included shipbuilders, army and naval officers, apothecaries and doctors. One distinguished doctor recruited by the later Romanovs, who plays an important part in the rhubarb story, was James Mounsey.

\section{How could the Russian monopoly be broken?}

From 1750 to 1850 Russia was making a fortune from trading rhubarb root through St Petersburg to Europe via the Baltic. Russia supplied and controlled the export of the dried root, thus controlling its price. It banned the export of the seeds to block the growing of the plant elsewhere. Catherine the Great took considerable interest in the cultivation and sale of rhubarb, as it helped to finance her military campaigns in Finland, Poland, Ukraine and Crimea. The price of rhubarb root rocketed! At one time the seeds were more valuable, weight for weight, than gold. To give some idea of the veneration that was given to the plant, Lord Stanhope, a Catholic peer, sent some rhubarb seeds to the Pope in a gold case, encouraging him to grow the plant in the gardens at the Vatican. This monopoly could not last indefinitely. Professor John Hope stated in 1770 that if 'Russian' rhubarb could be grown successfully in the UK, it would save the economy about $£ 1$ million a year (approximately $£ 20-30$ million in today's money).
Figure 2. James Mounsey. The 'frightened physician' who escaped from the Romanovs

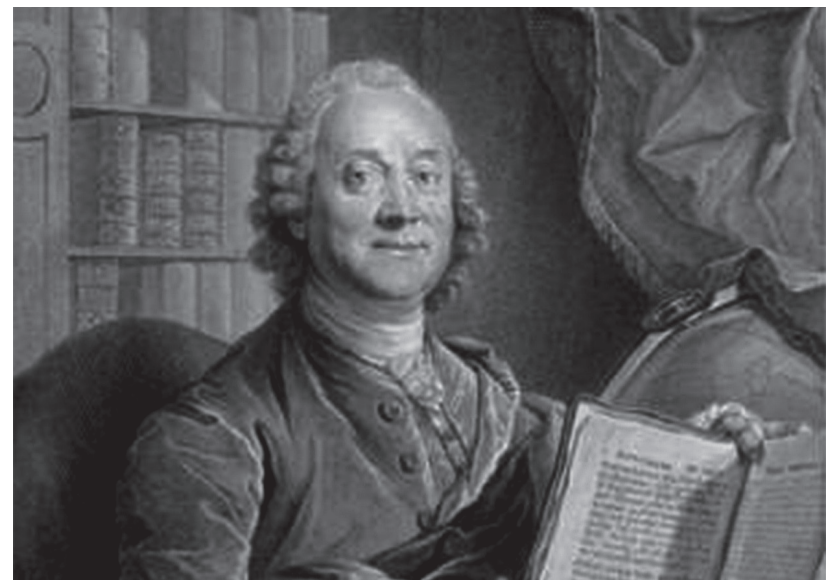

\section{Dr James Mounsey FRCPE, FRS $(\mathbf{1 7 1 0}-\mathbf{1 7 7 3})^{6,7}$}

Mounsey was born in Skipmyre, Dumfriesshire, and undertook his medical education at the University of Edinburgh, but did not graduate. He was fortunate to have several great teachers, in particular Monro primus, the first Professor of Anatomy at the University, and Charles Alston, who was the King's Botanist for Scotland and Keeper of the Royal Garden at Edinburgh (combining these roles with a Chair in Botany and Materia Medica at the city's University). In 1729, Alston presented Mounsey with a copy of his Index of Official plants growing in the Edinburgh Garden. It is known that Alston advocated the use of rhubarb in the flux (dysentery) that had struck down the Hanoverian troops after the battle of Culloden in 1746. The next we hear of Mounsey is in London, in July 1736, where Prince Kantemir of Russia recruited him to serve as a 'lekar' in the Naval Hospital at St Petersburg. At that time a 'lekar' was a medical man who had not yet received his doctor's degree. He then had two spells in the service of the Russian army, interrupted by his taking an MD degree at Rheims in France (Figure 2).

Mounsey rose rapidly through the ranks of the army before deciding to set up in private practice in Moscow, where his abilities came to the attention of the Empress Elizabeth. She appointed him as First Royal Physician with a rank of Privy Councillor and a large salary of 4,000 roubles a year. However, in 1761 Elizabeth became gravely ill. Mounsey was called, but she died on 25th December 1761 after a severe haemoptysis, diarrhoea and vomiting. Mounsey had bled her, but to no avail. Peter III, who followed her, immediately promoted Mounsey to the position of 'Archiator' which was the highest post in the medical services in the Russian Kingdom. Unfortunately for Mounsey, Peter III's reign would be extremely short. After six months he died in July 1762 . He was said to have developed a haemorrhoidal colic, but it is likely that he was poisoned with arsenic and then strangled. Peter III was very obviously suffering from a severe mental incapacity and his wife, Catherine II (the Great) (Figure 3), who immediately became the Empress after his death, is thought to have plotted the coup d'état with her lover. 
Figure 3. Catherine the Great and her husband Tsar Peter III, who was later assassinated by conspirators directed by Catherine and her lover

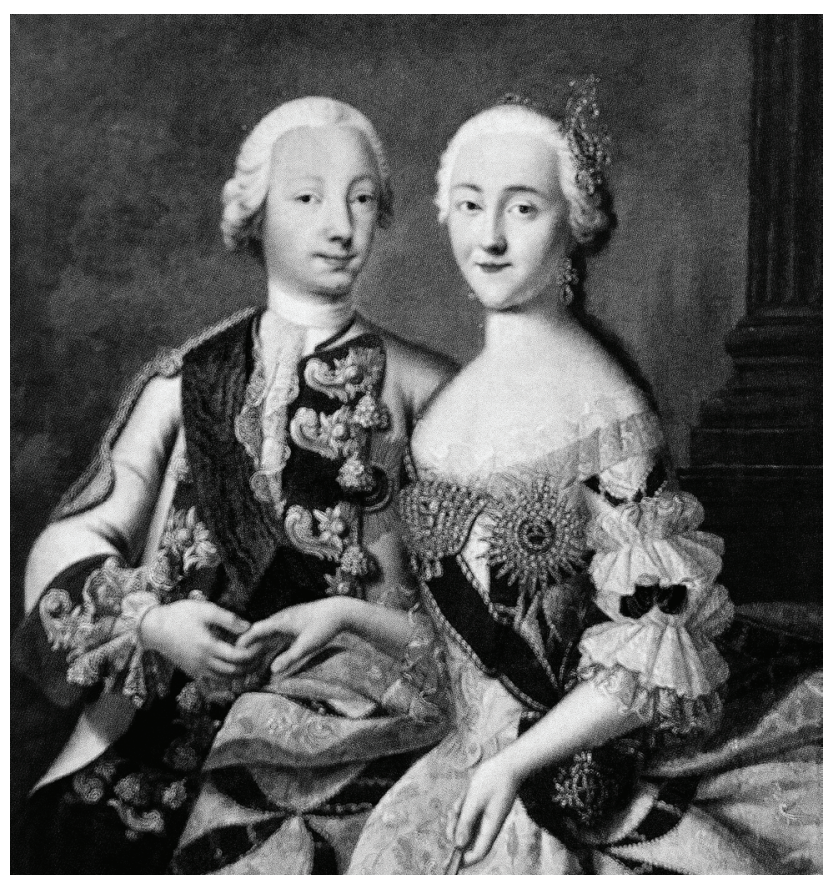

This untimely death of the Emperor placed Mounsey in a very difficult, indeed dangerous, position. When an emperor was deposed or died, it was well known that his close associates might, at best, be exiled to Siberia or, at worst, killed. Mounsey successfully petitioned Catherine II to allow him to retire on the grounds of 'ill health' (although it should be noted he then survived in Scotland for a further ten years). He had accumulated great personal wealth as a confidante at the Royal Court but, most importantly, he smuggled back several pounds of rhubarb seeds. The latter enterprise went directly against the ukase of the Russian Government which, although allowing the export of dried rhubarb roots under strict control, forbade the sending of rhubarb seeds abroad as this would breach the Russian monopoly (if they could be cultivated successfully).

Mounsey initially reestablished himself in Edinburgh before moving to Dumfriesshire in 1763 , where he bought the estate of Rammerscales, about four miles south of the village of Lochmaben. He built a substantial manor house there. For the remaining ten years of his life, he became something of a social recluse, perhaps because he thought the Russian Court might procure agents in Scotland to kill him. The smuggling of rhubarb seeds from the Botanic Garden at St Petersburg to Scotland would have weighed heavily against him. He slept with a loaded firearm by his bed and arranged for all the rooms in the house to have two doors, one of which might furnish a ready escape route. Two further stories, probably apocryphal, circulated among the natives of Lochmaben; the first that there was an underground escape passage from the house and second, that he had staged a mock funeral in order to put possible assassins off his scent!

His contribution to the development of rhubarb cultivation was inestimable. He was awarded the gold medal of the Royal Society of Arts in London in 1770 for his contribution
Figure 4. Memorial to James Mounsey in the churchyard at Lochmaben

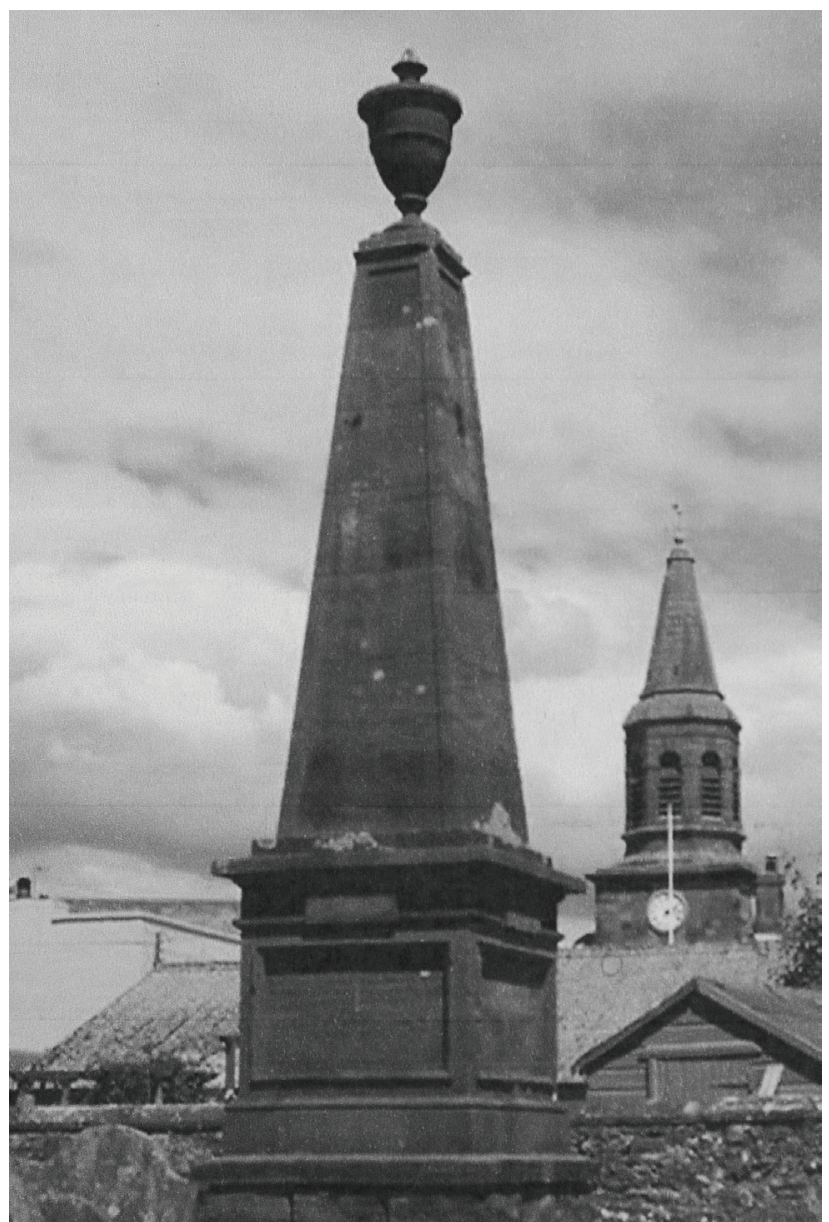

to the introduction of rhubarb into Great Britain. Mounsey died in 1773, at the age of 63 , and is buried in Lochmaben Churchyard where there is an imposing 30 feet tall granite memorial (Figure 4) which states:

In memory of Dr James Mounsey of Rammerscales who was First Physician to the Emperor and Empress of Russia. Born at Skipmire. Died in Edinburgh 2 Feb 1773

\section{Mounsey, Dick and Hope}

At a meeting of the Fellows of the Royal College of Physicians of Edinburgh in 1763, Dr Mounsey presented a pound of rhubarb seeds to Sir Alexander Dick, then President of the College, and to Dr John Hope, King's Botanist and Professor of Materia Medica. This meeting marked a critical point in the story of the cultivation of rhubarb in Edinburgh.

\section{Sir Alexander Dick FRCPE (1703-1785) and Prestonfield House ${ }^{8}$}

In 1746 Dick (Figure 5) moved to Edinburgh and practised medicine on a part-time basis as his main interests lay in scientific research and politics. In 1756 he was elected President of the Royal College of Physicians of Edinburgh. He held this post successfully for seven years before retiring voluntarily in 1763 , stating that 'other physicians deserved, on merit, to be elected and therefore there should be some rotation'. 
Figure 5. Alexander Dick, President of the RCPE 1756-1763

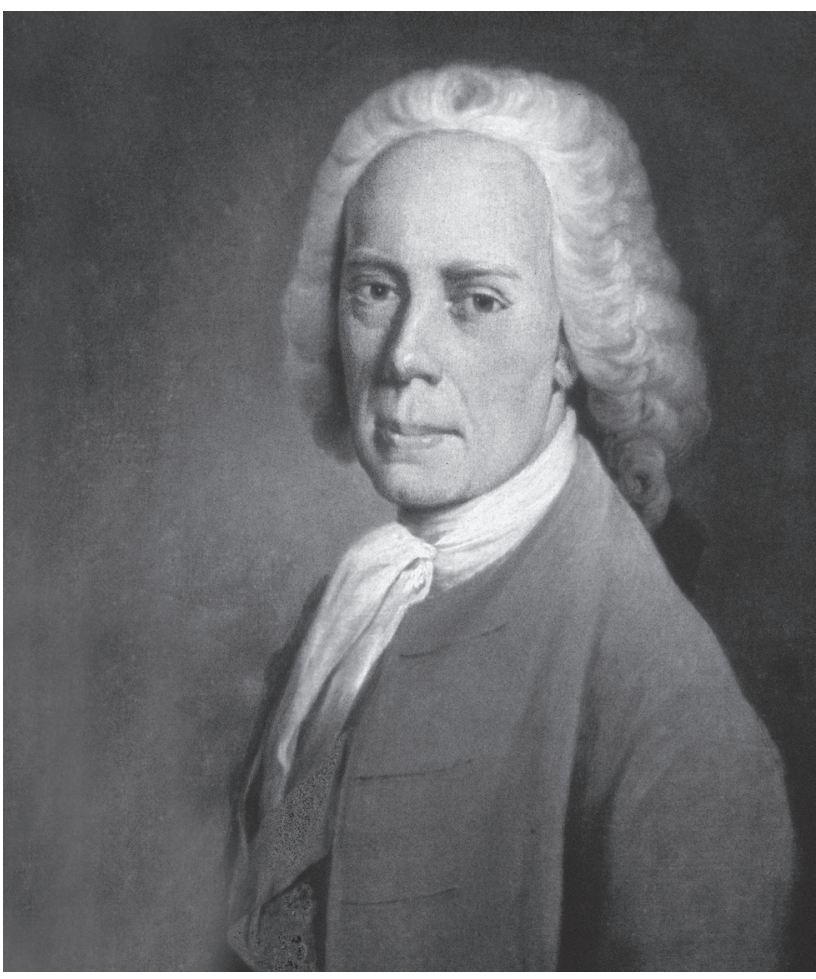

During his time as President (and afterwards) he contributed substantially to the building of the new Hall in George Street and helped to develop the library. He entertained a great number of luminaries at his home at Prestonfield House, including Benjamin Franklin and Samuel Johnson. Fascinated by botany he planted some of the Mounsey rhubarb seeds in the gardens at Prestonfield. For this activity, he too, like Mounsey, was awarded a gold medal by the Royal Society of Arts of London in 1770. Prestonfield is now a hotel but it retains its Georgian splendour. One of the restaurants is named Rhubarb in honour of Sir Alexander and his cultivation of the plant (Figure 6).

\section{Dr John Hope FRCPE (1725-1786) ${ }^{9}$}

John Hope (Figure 7) was born in Edinburgh on 10 May 1725. His father was a surgeon with an extensive Edinburgh practice. Hope obtained an MD at Glasgow University in 1750 and then studied in Paris where he came into contact with the works of Linnaeus, the great Swedish botanist. On his return to Scotland he was appointed Professor of Botany at the University of Edinburgh and King's Botanist for Scotland. In 1784 he was elected President of the Royal College of Physicians of Edinburgh.

Hope was the other doctor to receive rhubarb seeds from Mounsey in 1763. He acted immediately. First, he planted some of the seeds in the 'new' botanic garden at Leith Walk and second, he sent small amounts of seed to Kew Gardens and several Scottish lairds (including the Marquis of Bute). Hope feared that he (and Dick) would fail to cultivate rhubarb in the harsh winters of Edinburgh whereas on Bute (in the Gulf Stream) and in Kew Gardens in the south of England they might succeed if Edinburgh failed. He should not have worried - eventually he had over 3,000 rhubarb plants under cultivation at Leith Walk and began to sell rhubarb
Figure 6. Prestonfield House, ancient home of the Dick family in Edinburgh. The house was burnt down by a Protestant mob in the 1660s and then rebuilt

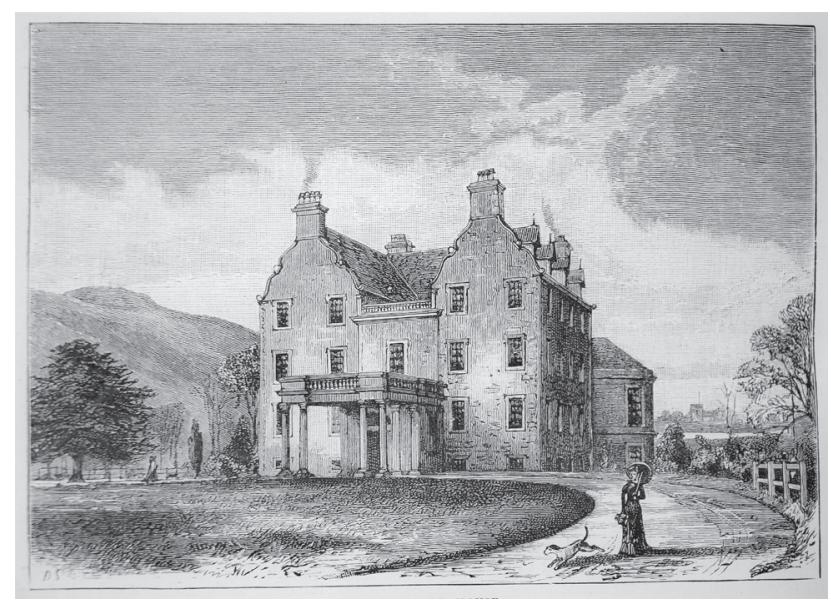

root commercially. Hope was in constant communication with botanists and gardeners all over the world including America, Canada, the Caribbean and Europe. In particular, he had a long correspondence with Linnaeus in Sweden. If Linnaeus was called the greatest botanist in the world when he introduced his binomial classification of plants (genus and species), then Hope deserved the title of the 'Scottish Linnaeus'. In fact, Hope adopted the Linnaean method of taxonomy as being superior to his own.

Originally Hope was responsible not only for the teaching of botany but also for instruction in Materia Medica. This burden was very great and Hope petitioned the Town Council (patrons of the University) to split his post into two parts. Dr

Figure 7. John Hope, President of the RCPE 1784-1786, seen here with his head gardener

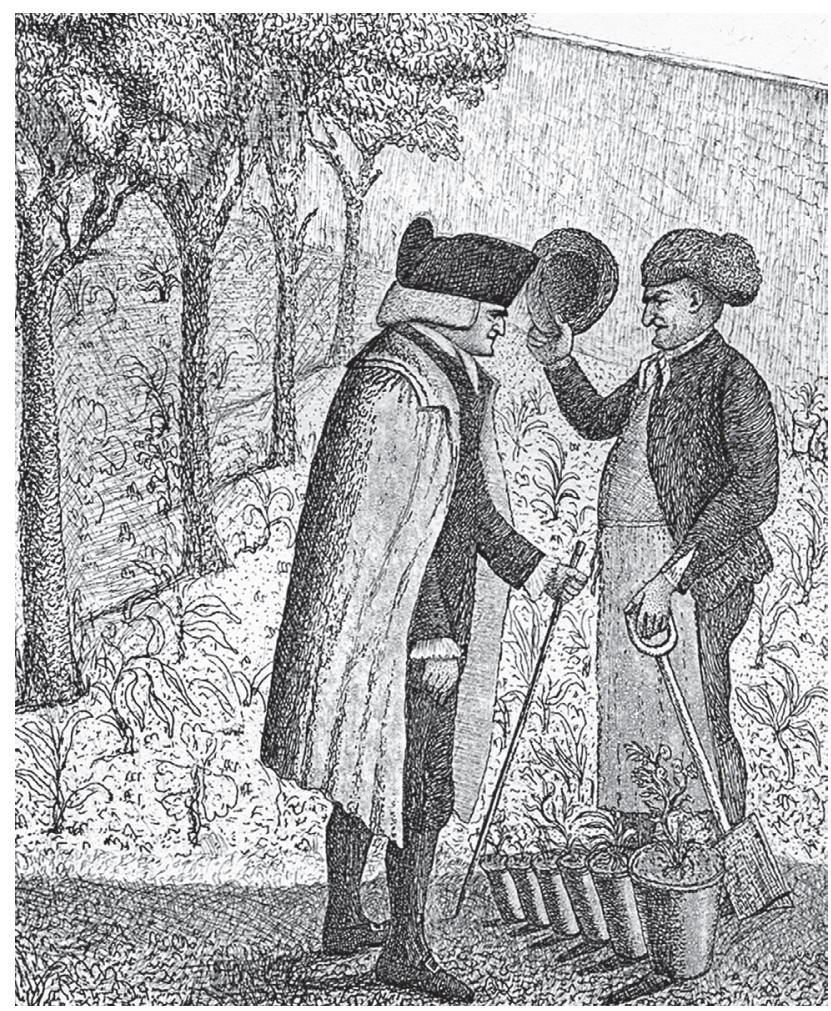


Francis Home became Regius Professor of Materia Medica and Hope continued with his botanical duties. He assessed all the plants he received as to their potential economic value as crops, medicines or dyestuffs. On his death he was widely described as a modest humane man devoted to learning of all kinds. He died suddenly and peacefully on 10th November 1786 and was interred in the Hope family burial ground in Greyfriars Church in the heart of Edinburgh.

\section{The Silk Road and the East India Company ${ }^{10}$}

At the end of the 18th century, as China began to develop contacts with the West, rhubarb merchants realised the price they were getting from the Russians was very low. They decided to seek other possible routes to the West which would bypass St Petersburg. The first and most obvious route was the long established Silk Road used for carrying precious cargos through the Central Asian states to the Levantine ports of the Ottoman Empire (then on to Venice and so to Europe).

After the Chinese permitted restricted access to the ports of Canton and Foochow (now Fuzhou), another, much quicker route developed. The Portuguese and the British East India Company took advantage of this new found freedom. The British East India Company had hundreds of ships trading with Egypt, the Arabian Peninsula and via the Cape of Good Hope with India (where they had massive commercial interests) (Figure 8). The ships were easily diverted to China and the amount of tea, rhubarb and other goods coming from the East increased exponentially. The price of rhubarb gradually began to fall and the export of rhubarb from Russia withered away.

\section{The commercial growing of rhubarb as a foodstuff in the UK}

The final blow to the high price of rhubarb was delivered by enterprising commercial growers in the UK who developed the techniques of 'forcing' (etiolation). ${ }^{11}$ Sometime around 1800 a fortuitous event occurred, when, according to legend, a gardener at Chelsea Physic Garden accidentally put a bucket over a rhubarb 'crown'. To his surprise, when the bucket was removed, the stems of the rhubarb had shot up and became a vibrant reddish yellow colour (etiolation due to lack of light). Moreover, the stems were much sweeter than those of the parent plant grown in the open air. The plants were frosted outside for a couple of months and then brought into the 'forcing sheds' lit only by candlelight. Bottom heat was applied by the use of coal. The sheds were constructed above the Yorkshire coalfield. Shoddy (woollen fibre), rich in nitrogen, was readily available from the nearby mills of Dewsbury and formed a perfect fertiliser. The smog and soot from the factories kept down pathogens particularly the fungus Botrytis.

At first there were several hundred small growers, but eventually two areas predominated. These were the village of Bodicote near Banbury (in Oxfordshire) and the West Yorkshire Triangle (based on the towns of Dewsbury and Wakefield). Yorkshire rhubarb came to dominate the commercial production of the plant in the UK. A specially designated train, 'The Rhubarb', ran regularly, non-stop, from Dewsbury to King's Cross taking rhubarb to the masses in
Figure 8. A typical ship of the East India Company, which transported rhubarb to the UK

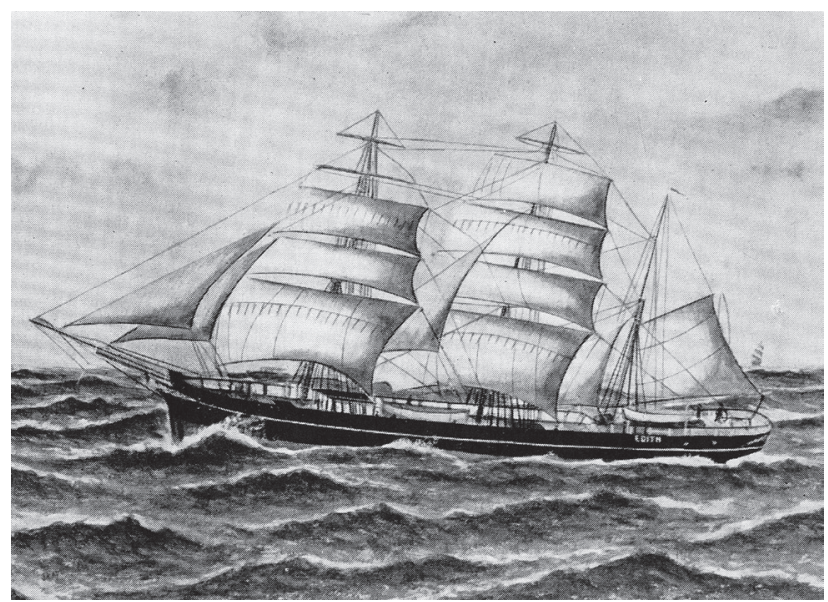

London. A number of cultivars were produced each with its own characteristics, including Cawood Delight, Champagne, Stockbridge Arrow, Timperley Early and Queen Victoria. The number of hybrids has now reached 120 and a national collection is kept at Clumber Park in Nottinghamshire. In 2010 the European Union recognised this excellence by awarding the area a Protected Designation of Origin status. Yorkshire rhubarb now ranks with Parma ham, Champagne and Stilton cheese (Figure 9).

Another development helped in the general adoption of rhubarb as a foodstuff. Many consumers had found rhubarb

Figure 9. Rhubarb sculpture, Thornes Park, Wakefield, West Yorkshire

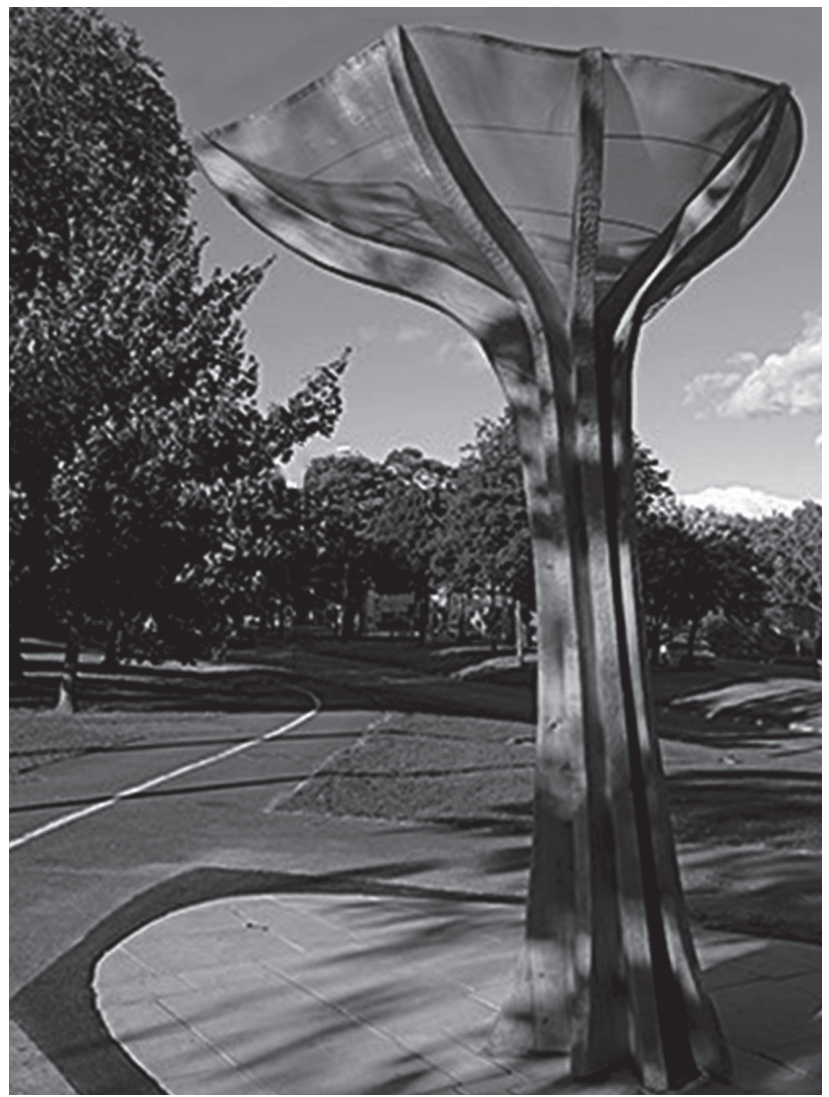


stalks 'tarty' due to the presence of oxalic acid and 'gritty' as a result of deposits of calcium oxalate crystals known as raphides (from the Greek for 'needles'). During the 19th century, as rhubarb became cheaper, another foodstuff appeared on the market, cane sugar from the West Indies. This plant, Saccharinum officinarum, ${ }^{12}$ contained large amounts of sucrose, a sweetener more powerful than those previously used, such as sweet cicely (Myrrha odorata) or liquorice (Glycyrrhiza officinarum). This disaccharide was added to many preparations of rhubarb, including tarts, puddings and jams, rendering them more palatable. 'Rhubarb and custard' became like 'fish and chips', a staple of the working class diet.

\section{Rhubarb as a purgative: from the ancients to modern times}

From the time of Hippocrates, Theophrastus and Dioscorides, physicians thought that in disease 'evil humours' possessed the body and that if these malevolent substances could be expelled then the malady would be cured. As a result of these ideas and before germ theory had emerged in the second half of the 19th century, practices such as bleeding, cupping, emesis, sweating and purgation were widely used. All of these methods were gradually dropped but purgation proved particularly resistant to modern ideas and went on being used well into the 20th century. Many weird and wonderful plant and mineral potions were in use as purgatives, including buckthorn, castor oil, colocynth, croton oil, jalap, podophyllum, scammony and Epsom salts $\left(\mathrm{Mg} \mathrm{So}_{4} 7 \mathrm{H}_{2} \mathrm{O}\right)$. Some of the purgatives were so violent that they were called hydragogue cathartics (water expelling) and could cause collapse or even death as a result of fluid loss from the bowel. A search developed for a milder laxative and rhubarb (and senna) came to the fore. This work was developed in particular by James Gregory of Edinburgh. He based his work on the herbals of Culpeper and others.

\section{James Gregory (1753-1821), the irascible physician $^{13}$}

\author{
'If in doubt lead with trumps, is counsel so old \\ as never fails with the game in a Fixture, \\ and medical men, if in doubt, \\ are safe when they lead with Gregory's Mixture'
}

An old saw (or saying) circulating in Edinburgh circa 1820.

James Gregory was born in Aberdeen in 1753 and subsequently attended the Universities of Edinburgh and Oxford. In June 1775 he took up the Chair of the Institutes of Medicine in Edinburgh at the extremely early age of 22 years. Gregory proved to be a superb lecturer (Figure 10).

During this time he wrote a new textbook of medicine which he called Conspectus Medicinae Theoreticae. It was very successful, passed through many editions and was translated into several languages (including English). He was even complimented on his beautiful Latin. At first Gregory lived in the city, but then moved to Canaan Lodge, in the salubrious suburb of Morningside. Here he could escape the smells and fog of 'Auld Reekie'. Gregory was notoriously
Figure 10. James Gregory, President of the RCPE 17981801 , known as 'the irascible physician'

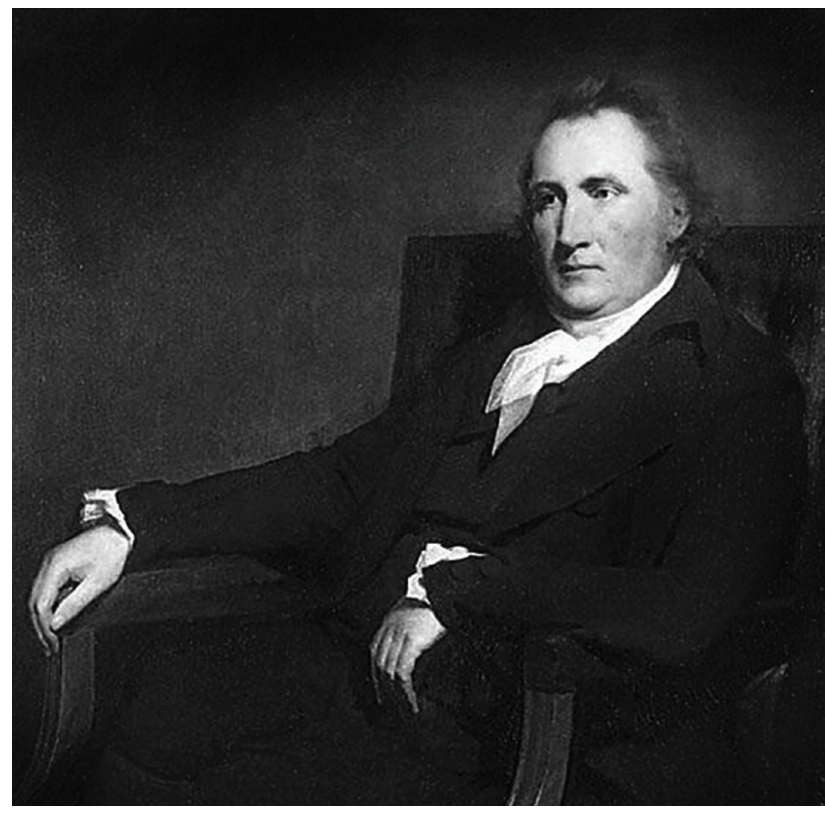

argumentative and after a quarrel with a fellow academic, Professor Hamilton, he smote him to the ground with his stick. Summoned to court he was found guilty of assault and fined $£ 100$ (a considerable amount in those days). He had the last word, however. On paying his fine, he said that 'he would willingly pay double to be allowed to repeat the assault'.

\section{Gregory's mixture: compound of rhubarb (Rheum)}

In spite of his conviction for assault, Gregory's medical practice expanded remarkably and by 1815 it is estimated that his annual earnings exceeded $£ 500,000$ (in present day terms). He was in demand all over Scotland for a second (or third) opinion. He wanted to develop a mild laxative and after some experimentation and study of the work of previous herbalists, he alighted on the following mixture:

- Rhubarb root (Rheum)

- Magnesia (Magnesium carbonate $\mathrm{Mg} \mathrm{CO}_{3}$ )

- Peppermint oil (Mentha) and

- Ginger root (Zingiber)

This was a happy combination of principles for various reasons: rhubarb was a mild laxative, magnesia was a useful antacid which promoted belching (as it released carbon dioxide when it reacted with hydrochloric acid in the stomach); ginger was a well-known carminative. Initially, the taste and nature of the mixture was compared, by patients, to that of swallowing 'brick dust'. ${ }^{14}$ As a result, Gregory added oil of peppermint to alleviate the foul taste. Peppermint was also a carminative and had been used for that purpose for many years.

Two of the ingredients of the mixture were readily available in Edinburgh: rhubarb and magnesia. The rhubarb came from Sir Alexander Dick's gardens at Prestonfield and magnesia was produced by Thomas Steel in his factory in Morningside, a short walk from Gregory's house at Canaan Lodge. Gregory's mixture became very popular straight away and within a few 
years the producers could barely keep pace with demand. There was scarcely a Scottish child who wasn't dosed regularly with 'Gregory's'. Pulvis Rhei Compositus (Gregory's mixture) first appeared in the British Pharmacopoeia in 1864 and for the last time in 1953.

Gregory died in April 1821 of a 'hydrothorax'. Tributes poured in from all over the world. In the light of his great service to the people of Edinburgh, the Town Council arranged a civic funeral which was attended by the great and good of Edinburgh. He was interred in the family vault in the Canongate Church in the High Street. Gregory was famous for his aphorisms and one of them should be remembered as being equally applicable to present day practice: 'The best physician is one who can distinguish what he can do from what he cannot do'.

\section{Rhubarb as a poison (oxalate and oxalosis) ${ }^{15}$}

Rhubarb can wear three hats: the root as a mild laxative, the stalk as a comestible and the leaf as a poison. The leaves of rhubarb contain needles of calcium oxalate. These give a sharp taste to the plant. Oxalic acid $(\mathrm{COOH})_{2}$ dicarboxylic acid is a deadly poison used widely in the cleaning and electrical industries and it can cause acute oxalosis. Its presence in the plant is presumably designed to deter predatory insects and birds. Many other plants and fungi contain dangerous amounts of oxalates, including the sorrels (Oxalis species), the common purslane (Portulaca olerocea) and the curly dock (Rumex crispus). Two moulds, Penicillium species and Aspergillus species also contain substantial amounts of the acid (and have on occasion caused poisoning). Many foodstuffs have high concentrations of oxalate. They include beet, chocolate, coconut, peanuts, potatoes, spinach, strawberries, black tea and wheat bran. Needless to say, these foods, fruits and sweets should be avoided totally in the primary genetic hyperoxalurias.

\section{The primary hyperoxalurias (inborn errors of metabolism) ${ }^{16}$}

In these genetic disorders, glyoxalate accumulates in the liver and is rapidly metabolised there to oxalate. When oxalate accumulates in the human body, it first depletes total body calcium, causing tetanic contractions, and then is deposited in the brain, heart and kidney resulting in coma, cardiac and renal failure (and subsequent death). There are three different and distinct enzymic deletions which occur in the glyoxalate cycle, $\mathrm{PH}_{1}, \mathrm{PH}_{2}$ and $\mathrm{PH}_{3}$. $\mathrm{PH}_{1}$ accounts for $80 \%$ of affected individuals with primary hyperoxaluria and death usually occurs before the age of 20 . The pathological diagnostic finding, in all of the affected tissues of the body, is the deposition of birefringent crystals of calcium oxalate.

\section{Is rhubarb dangerous to eat?}

Rhubarb stalks (pedicles) are safe to eat and poisoning is very rare, but eating the leaves can be dangerous. The toxic effects of rhubarb can be grouped under three categories: laxative abuse, mild systemic oxalosis and severe systemic oxalosis (leading very occasionally to death):

\section{Laxative abuse $^{17}$}

People with anorexia and/or bulimia often employ 'slimming pills' to help them achieve weight loss. Many of these preparations contain rhubarb and as a result hypokalaemia and both acute and chronic renal failure may ensue..$^{18}$

\section{Mild systemic oxalosis}

It is not uncommon for excessive consumption of rhubarb (or sorrel, usually in soups) to produce acute pain in the kidneys with haematuria. This syndrome is caused by microcrystals of calcium oxalate lodging in the kidneys, which produces renal colic. Occasionally, these microcrystals will aggregate to form macroscopic stones. They may pass into the urine spontaneously or necessitate lithotripsy (to break them up) or endoscopy (to remove them).

\section{Severe systemic oxalosis ${ }^{19}$}

This occurs rarely with exogenous rhubarb leaves, but certain conditions predispose to widespread oxalosis and death. They include:

- Undiagnosed hereditary hyperoxaluria

- The concomitant ingestion of other laxatives including cascara and senna

- The co-administration of nonsteroidal drugs such as ibuprofen and diclofenac which themselves can cause renal damage

- The presence of other renal pathological conditions such as glomerulonephritis and diabetic glomerulosclerosis

- Finally, and most importantly, young children are much more susceptible to oxalate poisoning than adults. Most of the very few deaths resulting from the ingestion of rhubarb have occurred in children under 10 years of age $\mathrm{e}^{20}$

\section{Conclusion: The 'All-Bran' of the Age of Reason}

Purging persisted well into the 20th century for two main reasons:

1. Faecal matter was regarded as poisonous and should be eliminated from the body regularly.

2. The residents of the polluted cities of the Industrial Revolution traditionally ate a low residue, low fibre diet with a minimum of fresh fruit and vegetables. As a result, they suffered from chronic constipation and pain on defecation. This led to the search for a 'perfect' laxative and one answer was rhubarb, which some historians have labelled the 'All-Bran' of the Age of Enlightenment.

The story related here is compelling. Rhubarb was, at first, so difficult to obtain that it generated an economic frenzy terminated only by the success of the British growers. Four Fellows of the Royal College of Physicians of Edinburgh played a distinguished part in the struggle to cultivate rhubarb in the UK (and to break the Russian monopoly). They were very different men: Mounsey (a frightened physician who took the first critical step), Hope (a generous and obsessional plant hunter) and Dick (a gregarious polymath) worked 
together to grow rhubarb in Edinburgh. Then finally, there was Gregory who, despite his petulant and argumentative nature, introduced one of the most successful laxatives of the 19th and 20th centuries. Dick, Hope and Gregory were at one time (or another) Presidents of the Royal College of Physicians of Edinburgh. They flourished (like rhubarb) in the 'forcing house' of the Age of the Scottish Enlightenment, their work unrestrained by the shibboleths of the ancient British institutions. A quotation from the Apocrypha (chapter 44 , verses 1 and 4$)^{21}$ is a fitting end to the 'wondrous' story of rhubarb and the critical contribution of Edinburgh physicians:

'Now let us praise famous men

and our fathers who begat us.

Leaders of the people by their counsels and by their knowledge of learning:

wise and eloquent in their instructions.'

\section{Acknowledgements}

We would like to recognise the following for their contributions to this paper: Reverend Paul Read, Lochmaben, for information and photographs concerning Mounsey; Dr Jack Wilson FRCPE, Lochmaben, for drawing our attention to his paper Three Scots in the service of the Czars $^{7}$ and to Mr Malcolm Bell MacDonald of Rammerscales House for further information on the 'frightened physician'. We also thank Barlow Moor Books, for their help in obtaining valuable material; Oldroyd's Rhubarb, Dewsbury, for their assistance with the history of the Rhubarb Triangle in West Yorkshire.

\section{References}

1 Foust CM. Rhubarb: The Wondrous Drug. Princeton, NJ: Princeton University Press; 1992. p.34-8.

2 Huang KC. The Pharmacology of Chinese Herbs. 2nd ed. Boca Raton, FL: CRC Press; 1999. p.233-4.

3 Farthing MJC. Nicholas Culpeper (1616-1654): London's first general practitioner? J Med Biogr 2015; 23: 152-8.

4 Culpeper N. Pharmacopoeia Londinensis, or, The London dispensatory: further adorned by the studies and collections of the Fellows, now living of the said colledg. London: Printed for Peter Cole; 1653.

5 Montefiore SS. The Romanovs: 1613-1918. London: Weidenfeld \& Nicolson; 2016. p.198-202.

6 Innes Smith R. Dr James Mounsey of Rammerscales. Edinb Med J 1926; 33: 274-9.

7 Wilson JB. Three Scots in the service of the Czars. The Practitioner 1973; 210: 569-74 and 704-8.

8 Harrison R. Dick, Sir Alexander, third baronet (1703-1785), rev. Wallis P. Oxford Dictionary of National Biography. http://www. oxforddnb.com/view/article/7592 (accessed January 2016).

9 Noltie HJ. John Hope, 1725-1768: Alan G. Morton's Memoir of a Scottish Botanist. Edinburgh: Royal Botanic Garden Edinburgh; 2011.

10 Keay J. The Honourable Company: A History of the English East India Company. London: Harper Collins; 1991.

11 Beck C. The forced is with us. Saga Magazine March 2016: 46-9.

12 Hyam R, Pankhurst R. Saccharinum officinarum. In: Plants and their Names: A Concise Dictionary. Oxford: Oxford University Press; 1995. p.441.
13 Passmore R. James Gregory 1753-1821. In: Passmore R. Fellows of Edinburgh's College of Physicians during the Scottish Enlightenment. Edinburgh: RCPE; 2001. p.76-8.

14 Butler, AR. The coming of rhubarb. Proceedings of the Scottish Society of the History of Medicine 1996: 52-5.

15 Barceloux DG. Rhubarb and oxalosis (Rheum species). In: Barceloux DG. Medical Toxicology of Natural Substances: Foods, Fungi, Medicinal Herbs, Plants and Venomous Animals. Hoboken, NJ: John Wiley and Sons; 2012. p.84-8.

16 Bhasin B, Ürekli HM, Atta MG. Primary and secondary hyperoxaluria: understanding the enigma. World I Nephrol 2015; 4: 235-44.

17 Polson CJ, Green MA, Lee MR. Clinical Toxicology. 3rd ed. London: Pitman; 1983; p.302-8.

$18 \mathrm{Kwan} \mathrm{TH}$, Tong $\mathrm{MKH}$, Leung $\mathrm{KT}$ et al. Acute renal failure associated with prolonged intake of slimming pills containing anthraquinones. Hong Kong Med J 2006; 12: 394-7.

19 Sanz P, Reig R. Clinical and pathological findings in fatal plant oxalosis. A review. Am J Forensic Med Pathol 1992; 13: 342-5.

20 Tallqvist $\mathrm{H}$, Vaananen I. Death of a child from oxalic acid poisoning due to eating rhubarb leaves. Ann Paediatr Fenn 1960; 6: $144-7$.

21 The Apocrypha: An addition to the King James Version of the Bible. Book of Ecclesiasticus. Chapter 44, verses 1 and 4 . Cambridge University Press. 